\title{
Leaving Productivism behind: Towards a Holistic and Processual Philosophy of Ecological Management
}

\author{
Pasi Heikkurinen $^{1,2}$ (D) Toni Ruuska $^{2} \cdot$ Anna Kuokkanen $^{3} \cdot$ Sally Russell $^{1}$ \\ Published online: 28 January 2019 \\ (C) The Author(s) 2019
}

\begin{abstract}
This article examines parallels between the increasing mental burnout and environmental overshoot in the organisational context. The article argues that there is a particular philosophy of management that connects these two phenomena of overshoot and burnout, namely productivism. As there are boundaries in all ecological processes and systems, the productivist aim of having ever more output and growth is deemed absurd. It is proposed that productivity as a management philosophy not only leads to mental illhealth in organisations but also to overshoot in the environment. The article concludes that productivism, which denies the limits in utilisation of humans and other natural resources, fits poorly with circular economy and sustainability. Hence, ecological management should be complemented with a more holistic and processual view of organizations, as well as have an aim of peaceful coexistence between all earthbound objects. This signifies acknowledging and caring for human and non-human needs both now and in future by applying the idea of moderation to production of goods and services.
\end{abstract}

Keywords Burnout $\cdot$ Management $\cdot$ Overshoot $\cdot$ Productivism $\cdot$ Sustainability

\section{Introduction}

Since the Industrial Revolution, environmental problems have been escalating (Barnosky et al. 2012; IPCC 2014). The undesired anthropogenic cause of the environment's inability to regenerate resources and absorb human wastes at the pace they are being produced has been referred to as 'overshoot' (Meadows et al. 1972, 2002). In its simplest

Pasi Heikkurinen

P.Heikkurinen@Leeds.ac.uk

1 Sustainability Research Institute, University of Leeds, Leeds, UK

2 Department of Economics and Management, University of Helsinki, Helsinki, Finland

3 Finnish Institute of Occupational Health, University of Helsinki, Helsinki, Finland 
form, this signifies that humans have reached the limits of the Earth's carrying capacity (Daily and Ehrlich 1992) and transgressed planetary boundaries central to ensure a safe human operating space (Rockström et al. 2009; Steffen et al. 2015). The overall negative human impact on the environment can be measured in terms of (the amount of) affluence and population (Chertow 2000; IPCC 2014), which owes to the organisation of human societies based on ideas of productivism: namely, the pursuit of indefinite growth and capital accumulation (Latouche 2007; Foster 2009).

Other serious problems within contemporary societies include work stress, feelings of inadequacy, and other (work-related) mental problems or 'burnout'. The latter half of the twentieth century, marked by a steep rise in productivity, has been a period when mental suffering has become a major concern of occupational health care professionals in many Western societies (Newton 1995; Horwitz 2002; Wainwright and Calnan 2002). The increase of mental disorder diagnoses has been attributed to societal changes, the transition of work from physical labour to cognitive processes, and the development of medical science and new diagnostic categories. The increasing intensification of work life (Green 2006) and new employee ideals emphasising entrepreneurialism (Miller and Rose 2008), to the more general rise of neoliberal organisation of global capitalism (Jones 2013; Robinson 2014; Scharff 2015) have also created new burdens on employees' psyches.

The organisation is a nexus that connects these two problems. On the one hand, they are 'a primary instrument by which humans impact their natural environment' (Shrivastava 1994, p. 705) and on the other, they are increasingly the places, as well as sources, of psychological damage (see Newton 1995; Väänänen et al. 2014). But is there a particular kind of management philosophy that could be considered the linking pin between the two phenomena of overshoot and burnout? And if so, what explains it? This article will address these questions conceptually and will seek to contribute to bridging the often separately discussed problems of overusing the mental and material resources of organisations. The article draws on the works of Gregory Bateson (1972, 1979) and Felix Guattari ([1989] 2000), as well as Marxist philosophy (Foster 2009; Althusser [1995] 2014; Moore 2015) to understand the organisation as an energetic process. The article proposes that the productivist philosophy of management, which assumes measurable productivity and growth as the purpose of management, poorly matches with the aims of circular economy and sustainability. The productivist principle, of having ever more output, is claimed to underlie both burnout and overshoot in the organisational context, as the productivist philosophy of management overlooks the limited resources in the human psyche and ignores the boundaries in the environment. The human psyche and the environment both require time for recovery, which signifies that those resources are not used. In terms of psyche and the environment, recovery begins when production slows down or comes to a halt. That is, while the most effective way to give the psyches a rest is to not require more output from them, the environment's healing starts when humans intervene less in the processes of nature. The article concludes that the productivist philosophy of management, which denies the limits of human and natural resources, is inherently unsustainable and should be complemented with a more holistic and processual view of organisations, as well as have an aim of peaceful coexistence between all earthbound objects. This signifies acknowledging the caring for human and non-human needs both now and in future by applying the idea of moderation to production of goods and services. 


\section{Ecological Management}

\section{Mind-Nature Dualism}

In line with the Cartesian tradition of science, the questions of 'mind' and 'matter' are often analysed separately, as two distinct categories or phenomena. That is, to a large extent the objective environment is still considered to consist of material objects and scrutinised in natural and environmental sciences, while the subjective mind is consistently investigated within the disciplines of psychology and philosophy, and as something only remotely connected to material processes. To study the mind as separate from matter in organisations also follows the dualist thinking of Descartes, where the two are assumed as completely different types of ontological substances, which one having priority over another (see e.g. Gupta 2017). Today, the mind-matter dualism, however, can be considered rather obsolete 'in that systems theory, cybernetics, holistic medicine, ecology, and gestalt psychology offer demonstrably better ways of understanding the world of biology and behaviour' (Bateson 1979, p. 218) beyond such a dichotomy. Contemporary theorising on organisation and management studies has also noted the limitations of Cartesian dualism (see e.g. Foster and Burkett 2000; Dale 2005; Nicholson and White 2006; Sandberg and Tsoukas 2015).

While there are several reasons to reject the mind-matter dualism (Knights 1997), perhaps the most obvious reason to move towards a non-dualistic approach in the study of organisational management is the unit of analysis itself, the organisation. An organisation is made of human and non-human actors, their will and action, as well as the structures that constrain them, manifesting in the spheres which are belong to both mind and matter. That is, in the language of physics: organisations comprise of both 'physical substances', such as buildings and flesh, and 'spirit', which occupies the space and possesses rest mass, especially as distinct from energy. In this article, however, this dualism is overcome by regarding both mind and matter as energy. Consequently, an organisation is conceptualised as a spatiotemporal concentration of energetic flows from the human and non-human worlds, where it is empirically impossible to pinpoint the boundaries between the registers of mind and matter. In other words, by this definition, an organisation is of both mind and matter (see e.g. Purser et al. 1995; Hart 1995). To deny this, even suggests that the dualist premise 'lead[s] to greed, monstrous over-growth, war, tyranny, and pollution' (Bateson 1979, p. 217).

The need for a more holistic and processual understanding is acknowledged particularly in the study of organisational sustainability. In their seminal article, Starik and Rands (1995), for instance, argue that in order to realise ecological management, it is necessary to examine the 'integrated web' of systems from the most micro individual level through to the macro level Earth system. To undertake such a research task signifies a profound intermingling of material and mental aspects in the theoretical framework, as well as a thorough transdisciplinary investigation on their relationships as a central aim of the study. The concept 'ecology' is well equipped for this task, as elaborated in the following section.

\section{Three Ecologies}

The etymology of the word 'ecology' comes from two sources in Greek. The first part of the concept, 'oikos', refers to a house or an environment, and the latter, 'logos', the study of something. Consequently, 'ecology' is conventionally understood as the study of the environment or 'nature's household', as the journal Ecological Economics (2017) defines it. This 
definition, however, is still prone to interpretations that are in line with, as well as reproduce, the dualist idea of mind and matter, as the conceptualisation of the ecology does not extend to the encompass questions on psyche.

To escape the Cartesian fallacy, Guattari ([1989] 2000) extends the definition of ecology from the natural environment to also encompass social relations and human subjectivity. Consequently, he talks about the 'environmental ecology', 'social ecology' and 'mental ecology' that are deeply intertwined and related, and 'all of which come under the ethico-aesthetic aegis of an ecosophy' (Guattari [1989] 2000, p. 41). He explains his ecosophy as follows:

'The increasing deterioration of human relations with the socius, the psyche and 'nature', is due not only to environmental and objective pollution but is also the result of a certain incomprehension and fatalistic passivity towards these issues as a whole, among both individuals and governments. Catastrophic or not, negative developments [évolutions] are simply accepted without question. Structuralism and subsequently postmodernism, has accustomed us to a vision of the world drained of the significance of human interventions, embodied as they are in concrete politics and micropolitics. The explanations offered for this decline of social praxes - the death of ideologies and the return to universal values - seem to me unsatisfactory. Rather, it appears to be a result of the failure of social and psychological praxes to adapt, as well as a certain blindness to the erroneousness of dividing the Real into a number of discrete domains. It is quite wrong to make a distinction between action on the psyche, the socius and the environment. Refusal to face up to the erosion of these three areas, [...] verges on a strategic infantilization of opinion and a destructive neutralization of democracy.'

What this quote importantly illustrates, is Guattari's rejection of any dualistic categories, and the call for processual holism. But to avoid anti-realism typical for the postmodern branch of organisation studies (Sheard 2009), where phenomena could not exist outside the human consciousness, the article calls for a sort of ecological realism (see Reed 1992; Bonnedahl and Caramujo 2018), which does not reduce existence to human perception and language. Furthermore, it is important to note here that 'communication, knowledge and language are [surely] dependent on distinctions and the classificatory schemes or typologies' [...] but it 'is only when [these] distinctions are transformed from heuristic devices into reified ontological realities that they become dualistic' (Knights 1997, p. 4), and problematic. That is, this article is not hostile towards using 'mind' and 'matter' as analytical categories in ecological management, as long as 'perceiving, far from being the kind of mental processing so much talked about by modern philosophers and psychologists, is [considered to be] part of a very ecological process of living in the world as an organism' (Reed 1992, p. 10). In other words, and following the work of Marjorie Grene, perception is assumed to be the 'awareness of the active self in a complex but at least partially comprehensible world' (ibid, p. 11).

It is perhaps meaningful to make parallels with the three ecologies of Guattari to the study of ecological management, as well as then apply them heuristically to study the links between them. The environmental ecology that Guattari refers to seems to be largely expressive of the so-called material sphere of management that is under scrutiny particularly in the field of environmental sciences. In terms of the matter-mind dualism, it prioritises to the preceding substance. The latter substance again, mind, is closely corresponding with the Guattarian idea 
of mental ecology. This aspect of ecological management is studied particularly in the field of environmental psychology. The third ecology that Guattari theorises, namely social ecology, is pertinent to connect with the social organisation.

In the study of ecological management, the emphasis on the oneness and interconnectedness of the mind (or mental ecology) and matter (or environmental) praxes is of great interest. This, of course, is not to denote that there are no differences in the ecologies of mind and matter. 'The[ir] contrast lies in this: that, for the material universe, we shall commonly be able to say that the "cause" of an event is some force or impact exerted upon some part of the material system by some one other part. One part acts upon another part. In contrast, in the world of ideas, it takes a relationship, either between two parts or between a part at time 1 and the same part at time 2, to activate some third component which we may call the receiver.' (Bateson 1979, p. 94). But, as Reed (1992, p. 11) notes, '[w] hat is explored in perceiving is not one's mind, nor the objects around one, but information' about a particular ecology. From the point of view of an ecological management philosophy, what 'the receiver (e.g., a sensory end organ) responds to is a difference or a change' (Bateson 1979, p. 94), but the enquiry is equally committed to understanding the shared experience of a particular aspect of reality, e.g. answering the question how ecological a certain kind of management practice actually is.

\section{Organisation as a Social Ecology}

Are contemporary management practices and organisations not only meeting places, but also the main sources of problems related to both mind and matter? And what kind of management philosophy connects these two forms of harms that are related to and mediated by organisations?

Recent studies on the environmental crisis have underscored the importance of 'the social' (Böhm et al. 2015; Finley 2018), as well as the role of the psychological dimension in solving the pressing ecological problems of the present time (Fisher 2013; Clayton et al. 2016). The relationship between overshoot and burnout is particularly relevant when studying, for instance, the role of corporate sustainability specialists. Wright and Nyberg (2012), for example, found that sustainability professionals have identified overshoot in the environmental ecology and are passionate to address it within the organisational realm. The impact is that these proponents of the environment must reconcile their own emotional engagement with addressing climate change while at the same time reconciling the negative impact of economic activities on the environment. Thus, the organisation becomes a site of reflection and tension regarding mind and matter.

Inherent in ecological management is a multilevel perspective that crosses disciplinary boundaries (e.g. Heikkurinen and Mäkinen 2018; Bonnedahl and Heikkurinen 2019). Indeed, this research draws on the fields of psychology, sociology, philosophy and anthropology (Heikkurinen 2017). Yet, the transdisciplinary research stream on connections between multiple levels of analysis has been lacking until very recently. Indeed, most scholarship has been dominated by work that examines organisational and industry focused phenomena with very little attention on the group and individual levels (Andersson et al. 2013). That trend is changing as more research examines the role of individuals in addressing environmental and social questions (e.g., Andersson et al. 2013; Bissing-Olson et al. 2013; Robertson and Barling 2013). Also the 'micro-CSR debate' (e.g. Glavas 2016) is an interesting extension towards the aspect of 'mind' in and of the organisation, albeit still largely sticking to the Cartesian presumption of mind versus matter. 
To exit this bifurcation of nature in management studies, requires holistic and processual thinking (e.g. Whitehead [1919] 1964) that integrates all levels of analysis in the organisational nexus, as well as taking a transdisciplinary perspective to the study of ecological management. For example, when Starik and Rands (1995) describe organisational systems as a web, they suggest that integration of mind and matter is necessary. Indeed, management research has been evolving in this direction (albeit slowly) and there has been increasing emphasis on all parts of the integrated web. What is missing, however, is an emphasis or examination of the web itself with its relations, or what this article refers to as the 'nexus'. The article defines the nexus as the level of analysis in between mind and matter, which in this case is the organisation, where all socio-political questions are present in the praxis.

A key premise of the present article is that this nexus is fundamental to understanding the ecological crises and enacting ecological management proper. In many current management models there is an inherent assumption of connectedness within and between levels of analysis, yet very few scholars articulate or investigate this relation. Following the Guattarian and Batesonian thinking, the issues faced in terms of matter in the environmental ecology are mirrored at the individual level in the mental ecology, and vice versa. By developing a holistic, processual perspective on ecological management, there is a better chance to begin to see the parallels and connections between burnout and the overshoot.

Before being able to address the main question about the kind of management philosophy that connects the two phenomena of overshoot and burnout, there is a need for a closer look at the link between environmental ecology and organisation management, as well as the mental ecology and organisation management.

\section{Mental Ecology Problems}

Mental disorders have increased in many Western societies since the 1970s (e.g. Bültmann et al. 2008; Hensing et al. 2006; Järvisalo et al. 2005; Knudsen et al. 2010), causing a significant amount of human suffering and lost work years. Subsequently, this has increased concern regarding employees' mental health in recent decades (Newton 1995; Horwitz 2002; Dewe et al. 2012; Väänänen et al. 2012, 2014). But what kind of management of human activities has led to the ecological crisis of the mind?

Work-related mental health problems such as work stress and burnout have been labelled epidemics due to their vast prevalence (Newton et al. 1995; Wainwright and Calnan 2002). The deteriorating mental wellbeing of the working-age population has also been perceived as a paradox, as working conditions and general standards of living developed mostly positively during the late 1900s (Green 2006; Brinkmann 2016). There is really no consensus among researchers over the reasons behind the growth of mental health problems, as mental health problems at work are considered to be a result of several intertwined societal changes. Many aspects of societal and management change such as intensifying competition between companies, growing requirement for efficiency, individualism, as well as medical development, such as the creation of new diagnostic categories for mental disorders during the end of the $1900 \mathrm{~s}$, have to be taken into account when assessing the increase of mental health problems at work. However, research has shown (Newton 1995; Shorter 1998; Kuokkanen et al. 2013; Väänänen et al. 2014) that 
it seems plausible to argue that some recent changes in production and the current management of organisations are causing a psychological burden for employees. Hence, this article will concentrate on the dimensions related to the transformation of work and production in recent decades.

Firstly, the management's requirements and skill demands are changing fast. The period from the 1960 s to the 2010 s was characterised by significant technological development and consequently, a substantial increase in requirements for educational degrees and a new kind of focus on social, emotional and cognitive skills at work. Globalisation and growing international competition have further increased the quality and quantity of these requirements (e.g., Boxall and Macky 2014; Green 2006). Consequently, many employees nowadays find it challenging to adjust to the current demands of organisational life, where more and better outputs must be produced. They are reported to suffer from stress, exhaustion and feelings of insufficiency as they have difficulties managing themselves and activities of their co-workers. The work of several people has also been transformed from physical labour to cognitive processes, which adds to the employees' mental load.

Secondly, management requires employees to be increasingly personally committed to and inwardly motivated by their work (Brown and Hesketh 2004; Kuokkanen et al. 2013). Contemporary management models inspired by organisational culture theories invite employees to form strong teams and regard their team members almost like their family members (Casey 1995, p. 181). However, this discourse may seem empty to an employee who does not see a connection between risks and rewards at work, does not regard the outcome of their work meaningful or does not feel needed. Moreover, according to Sennett (1998, p. 147), late capitalism creates 'the corrosion of character' among employees. This refers to a feeling of meaninglessness - a feeling that one is not truly needed. However, whether this is the fault of capitalism or something even deeper remains an open question. What can be stated at least is that current management practices often fail in creating a feeling of continuity and purpose, which is not necessarily only due to bad managers but an overall management philosophy driving the development.

Thirdly, work has become less satisfying for many employees. Even though income has grown, a decline in two important aspects of job quality - the overall level of job satisfaction and the extent of work strain - have been reported (Green 2004). The principles of New Public Management have generated protests from many professional groups in various sectors (Bezes et al. 2012). While current lines of development enrich many people's work, there has also been an opposite trend of deskilling and a decline in discretion due to outsourcing and subcontracting (Grugulis et al. 2003), which take away employees' autonomy in their work process.

It goes without saying that the impact of the increasing insecurity of work life needs to be taken into account when assessing the mental burden of work. The cycle of management changes in organisations has accelerated, causing negative impacts on employees' health (Kivimäki et al. 2000). The whole concept of the organisation has also changed, and work has become increasingly virtual with many people working remotely or as freelancers. These changes may cause feelings of insecurity and lack of commitment among employees (Burke and Cooper 2000, p. 14). Thus, while working conditions have improved in many respects during recent decades, it seems that management in increasingly competitive global markets and the consequent intensification of production have also deteriorated work for many, making employees increasingly vulnerable to stress, strain and burnout. What seems to connect the 
management philosophies compatible with capitalism and globalisation is the productivist idea of infinite resources, be they mental or environmental.

\section{Environmental Ecology Problems}

What about the relationship between the deterioration of the environment ecology and organisational management? What kind of management of activities have led to the ecological crisis of the 'matter'? To begin outlining an answer to this question, it is worth restating that the latter half of the twentieth century has been characterised by a steep rise in economic production and escalating ecological problems (Foster 2009; IPCC 2014). Expanding industrialisation, led by the capitalist mode of production (Althusser [1995] 2014), has shifted the emphasis of human management from the values of delivering utility and use to values focused on providing quantity and exchange, thus emphasising the search for continuous accumulation of capital (Harvey 2014). The result has been the upswing of the productivist philosophy of management, which is marked by the belief that measurable productivity and material wealth is the main aim of human management. The productivist idea of an ever-increasing input-output ratio, as a means to accumulate ever more wealth, has not only led to stress, strain and burnout within productivist organisations, as discussed before, but has also contributed to the overshoot in the biosphere (see Meadows et al. 1972, 2002; Foster et al. 2010).

The ecological crisis, as an outcome of the human-induced biospheric overshoot, is often reduced to a single phenomenon, such as climate change (IPCC 2014). To address the whole gamut of the crises, and to find means to a sustainable return within the planetary boundaries (Rockström et al. 2009; Steffen et al. 2015), however, would mean that all other aspects of the ecological destruction, such as the dramatic decline in biodiversity, surge in biochemical flows and the vast changes in land-systems, are to be considered as well (Steffen et al. 2015).

While the ecological crisis is a serious and complex phenomenon, the mitigation of it should not be. Arguably, an effective way to correct the overshoot is to produce and consume less in material terms. But, as Foster et al. (2010, p. 17) note, the essential problem concerning the ecological crisis is the unavoidable fact that an expanding economic system is placing additional burdens on a fixed earth system to the point of planetary overload.' In other words, one of the key questions of the present time is how to manage a transformation of an economic organisation, which is at its current capitalist form based on growth and continuous accumulation of wealth, to an organisation that reduces material throughput rather than increasing it?

As a prime manifestation of the productivist philosophy, capitalism has primarily developed to its current industrial form within the past two centuries (Polanyi [1944] 1968; Wood 2002) and become the predominant mode of production characterised by an organisation of expansive capital accumulation. But what is capital? In its simplest form, it is wealth. But as Wallerstein (2003, p. 13-14) compellingly argues, capital, as a part of capitalist historical social organisation, has a more specific definition. In this context, capital does not only denote to factories, machinery, IPR claims, etc., but has essentially been a process in which wealth has been 'used with the primary objective or intent of self-expansion' (Wallerstein 2003, p. 13-14; see also Harvey 2014). Consequently, capitalist management is the constant and endless pursuit of the accumulation of capital (cf. Ruuska 2017). 
Because of this, there are, indeed, persuasive reasons to argue, that there exists an absolute contradiction between capitalism and the finite planet Earth (Foster 2009). The authors of The Limits to Growth already noted this contradiction forty years ago. Meadows et al. wrote (1972, p. 46) that:

Much of each year's output is consumable goods, such as textiles, automobiles, and houses that leave the industrial system. But some fraction of the production is more capital - looms, steel mills, lathes - which is an investment to increase the capital stock. [...] More capital creates more output, some variable fraction of the output is investment, and more investment means more capital. The new, larger capital stock generates more output, and so on.

In other words, while capitalist production prevails, the reproduction of the mode of production requires more and more natural resources and labour (human or machine) to sustain economic growth, capital circulation and further accumulation of capital (Foster 2009; Moore 2015). Thus, it can be argued, on the one hand, that capitalist modes of production have supported productivist management philosophies (manifested in growth-fixated corporations and states). On the other hand it can be argued that the productivist philosophies of management keep on legitimating and supporting the reproduction of capitalist modes of production. That is, there is a fruitful interplay between the productivist philosophies of management and their manifestations, such as capitalist organisations, to relentlessly drive the growth agenda.

While it is increasingly acknowledged that the capitalist rationale and industrial production is to a large extent behind the destruction of human and non-human life, and one of the main reasons why ecosystems are pushed towards tipping points, neither mainstream politics nor environmentalism has been successful in addressing these issues (Klein 2014). Rather, what has been proposed as a means to alleviate the ongoing ecological crisis, are 'greener' and 'lighter' versions of capitalist production both materially (e.g. decoupling) and mentally (e.g. downshifting). In the respect of material production, there are two primary narratives to consider. The first relates to decoupling of economic growth and environmental harm (see e.g. Jackson 2009; Wiedmann et al. 2015; Ward et al. 2016), and the second to so-called cleaner technologies (see e.g. Foster 2009; Hornborg 2014; Heikkurinen 2018).

As Harvey (2014) argues, without expansion and gains in productivity there can be no capital. Economic growth, upon which the reproduction of the capitalist production and management depends, is both due to additional production involving increase in material throughput, and growth in productivity. Conversely, to claim that profits can be produced immaterially, for example from information, separated and without an increase in the material throughput, is problematic to say the least (see e.g. York 2006; Victor 2008; Jackson 2009; Ward et al. 2016). In terms of empirical research, there is to be found strong pieces of evidence suggesting that there exists a strong correlation between economic growth and environmental destruction (IPCC 2014; Wiedmann et al. 2015; Ward et al. 2016).

The same argument can be put forward also concerning technological improvement. Considering biospheric overshoot as an outcome of expansive material production, it has to be noted that no technological solution is created out of thin air (Georgescu-Roegen 1999; Foster 2009; Hornborg 2014). Also in this regard it is often neglected that in deeply capitalist organisations and societies, savings in one place are used to promote new capital formation and the proliferation of commodities elsewhere, demanding ever greater natural resources (Foster 2009). Even importantly for the aspiration to find and enact an ecological management 
philosophy, industrial surplus creation generates higher entropy, or disorder in nature. As Nicolas Georgescu-Roegen's (1999) seminal work convincingly points out, there are absolute physical limits to growth and resource extraction, ultimately defined by the laws of thermodynamics. Although, it is wise to remain cautious and perhaps not to try to predict the precise moment in history when we are to reach such material limits, it is still clear that the limits exist (Hornborg 2014; Moore 2015).

\section{Discussion}

While all species are claimed to engage in 'management' (Dibben and D'Arcy 2015), humans seem to be the only species that engages in management by the principle of productivism. That is, the human management of things and processes is largely defined by the idea of producing ever-more goods and services that have nothing (or very little) to do with meeting the basic needs, e.g. of food and shelter. And if we observe the actions of other species, arguably, they do not share the productivist belief that measurable productivity and growth are the purpose of organized activity, at least this does not reflect in the activities. Ecological management could hence perhaps be used to describe the parallels between humans' and other species' management praxis. An ecological management philosophy imagined in this article is not ruled by productivism but is rather based on peaceful coexistence, where a key aim is to not deny earthbound objects' existence and possibility to unfold their complex genesis. Unlike productivism, ecological management is not fixated to finding solutions merely by means of more technology. Instead, as Schumacher ([1973] 1974, p. 16-17) noted, 'we can interest ourselves in the evolution of small-scale technology, relatively non-violent technology, 'technology with a human face', so that people have a change to enjoy themselves while they are working [...]'. In addition, to applying technology in a scaled way that is in accord with the setting and more meaningful from the humanist point of view, less control of nature should be aimed for to enable the rest of nature to act as agent of its own (Heikkurinen 2018; Heikkurinen 2019).

Such philosophy is important in the transition to circular bioeconomy and other modes of organization that seek to contribute to sustainability, as it accepts that both mind and matter, or mind-matter, have limits that should not be exceeded. As regards these limits, and similarly to the findings of planetary boundaries (Rockström et al. 2009), the human psyche has limits that can perhaps be transgressed in the short term, but to do so over the long term has devastating effects. As Vetlesen (2016, p. 36) notes, correspondingly to external ecosystems, the resources of the mental ecology 'may be over-used and over-stretched - referred to as overshoot in the [environmental] ecological realm and burnout in the psychic one.' This observation is arguably of vital importance for managing ecologically. Indeed, to realise that ecological management means to recognise the limits of matter and mind in, as well as around, organisations.

From the process thought of Bateson and Guattari, the article draws the following parallels between the problems related to mind and matter. To overshoot the environmental ecology is to overuse the resources/energy of the material ecology, e.g. fossil fuels and shoals of fish. In a similar fashion, to burnout the mental ecology is to overuse of the resources/energy of the mind ecology. The ecological management practices relating to productivism, which today are largely manifested as capitalist processes of expansion and accumulation, are considered to be the nexus where its actors decide (more or less democratically) how resources will be used for the purposes of the organisation. As a consequence of the currently dominant mode 
management, which can be referred to as 'productivist', the working conditions and wealth of many organisations and societies have increased during the past decades. However, it is also clear that the productivist management philosophy with its insatiable need for more and more results in the form of mental outputs (e.g. more creative and innovative ideas) and material outputs (e.g. more products and services) has deteriorated the ecologies. It has not only negatively influenced the mental ecology of many by making employees increasingly vulnerable to stress, strain and burnout, but also damaged the environmental ecology by overusing of natural resources, destroying non-human habitats, and produced pollution, including the manufacture of harmful greenhouse gases. The intention is not only to link the destruction of ecologies to capitalism, but to productivist philosophies of management in general. Many socialist philosophies have in fact also been productivist. For example, most streams of "Marxism and neo-Marxism do not reject industry and technology, but only their capitalistic organization" (Severino [1982] 2016, p. 6). Such anti-capitalism is important, but arguably not sufficient to drive the required transformation away from productivism. Hence, as productivist management philosophies deny any boundaries in mind and matter, they can be considered quite absurd, even leading to nihilism. That is, where is the meaning in management if it is destined to be merely a technical exercise of ever increasing the output of production? Such one-dimensionality is not only a failing management philosophy but also a dangerous myth that is jeopardising the existence of diverse life on Earth.

Hence, to the question whether there is a particular philosophy of management that could be considered the linking pin between the undesired phenomena of overshoot and burnout, the article claims 'yes'. The article proposes that the destruction of ecologies largely owes to the idea of productivism enacted in practice, such as in capitalist organisation, without being limited to it. What connects globalisation, capitalist expansion and accumulation, and current business management practices is the productivist idea of extracting the infinite resources of the world, be they mental, social or environmental. The productivist management philosophy and its practices can thus be considered the connector between the problems of mental and environmental ecology.

What explains this is that, in productivist organisations, such as in corporations, there are similar management dynamics in how problems (of ecology) emerge as a consequence of the idea of ever-increasing productivity of the organisation. In fact, there is little evidence to support the notion that productivist organisations would either acknowledge or respect the mental and material limits inherently related to their management. Only until recently, a space for questioning growth in production and productivity has emerged in the study of organisations. As Shrivastava $(2015$, p. 1) aptly remarks, '[s]tarting to question this growth ideology is a major challenge facing management research. However, we need to remind ourselves that we can and we must shake some of these basic assumptions which are making us go around in circles.'

The so-called degrowth scholars have also importantly noted that resources in the environmental ecology are finite, and that one cannot substitute lost resources with another of a different kind (Latouche 2007; Victor 2008; Jackson 2009). It might well be that by accepting boundaries in ecology is prone to lead to also perceiving boundaries in the other ecological registers, particularly if the Cartesian dualist premise on mind-matter dualism is rejected. That is, as the ecologies are not separate, then the mental ecology can be considered finite and its resources non-substitutable. A beautiful day missed due to a mental illness cannot be substituted with money, prestige or even another day. It is gone in the same way a species is lost because of global warming or deforestation. And it goes the other way as well. That is, if the 
limits of environmental ecology are not recognised but rejected, perhaps the limits of mental ecology also remain unrecognised and rejected. There must at least be a connection between these two processes, if their intertwined relation of ecologies is accepted.

In contrast to the productivist philosophy of management, which is driven by the assumption that the purpose of management is to ensure growth (which, by the way, is the philosophy of a cancer cell), an ecological management is not production-led, but based on meeting the needs of earthbound actors. This is effectively ensured by an Aristotelian virtue of moderation in resource and energy use. In this sense, this article somewhat makes a departure from classic Marxist literature (e.g. Marx [1867] 1973; Althusser [1995] 2014), which is production-based. It is, of course, true that before doing anything else humans have to produce their subsistence (food, shelter, clothes, etc.). And this way the remarks of Marx (see Eagleton 2011) and Althusser ([1995] 2014, p. 22), for instance, are convincingly needs-based, which also acknowledge the principles of scarcity and moderation in resource and energy use (see e.g. Marx [1894] 1959, p. 593). But, they are also reductionist, in a perspective that Taylor (2007, p. 18) calls self-sufficient or exclusive humanism, i.e., 'humanism accepting no final goals beyond human flourishing, nor any allegiance to anything else beyond this flourishing'. Although Marx ([1844] 2011, p. 156), for instance, perceived very clearly that humans are part of nature, one species among many, he nevertheless saw that the interaction between humans and human external nature, especially through labour, is primarily oriented towards human flourishing as the end (Eagleton 2011; Marx [1867] 1973, p. 177).

In contrast to anthropocentrism, a holistic or an ecocentric philosophy of management (see Heikkurinen et al. 2016) does not deny human flourishing or its importance as a life-goal for humans, but rather argues that this goal is as important as other 'goals' in the web of life, and the flourishing of ecosystems (whole) is more important than human flourishing (part of the whole), and that these different types of flourishing are interconnected, albeit not in equal terms. This is because humans are dependent on ecosystems, but ecosystems are not dependent on humans (Heikkurinen et al. 2016). By no means, does the biosphere reduce to a mere resource for human flourishing, but serves a greater purpose (than just human ends) for flourishing of earthbound life in general. It is rather obscure to consider humans as separate agents with exclusive rights and ends in the web of life where everything is interconnected and causally linked. Or in another words, humans are in no position to make exclusive claims for flourishing at the expense of the rest of the biosphere. In this way, ecological management has be based on the principles of embeddedness in and dependency on the greater cosmos and surrounding ecosystems, but also to the right for other beings to exist and flourish as particles of whole (ibid).

The article hence calls for a holistic and processual take on management philosophy that challenges the productivist goal of always having more output. While management can be considered inherent in humans and nature at large (Dibben and D'Arcy 2015), productivist management cannot be a universal aspect of a meaningful life as it is puts human, and earthbound life overall, in jeopardy. There are boundaries in all ecological processes and systems, and for this reason it is impossible to achieve ever-increasing cumulative outputs and always more human affluence. Narrowly defined productivist ideals of success not only lead to mental ill-health in organisations but also to overshoot in the environment. Consequently, this article suggests that a fundamental tenet of ecological management is that it seeks to remains within the ecological boundaries (in both mental and matter terms), as well as supports others to do the same. This necessitates the replacing productivist management and the underpinning mind-matter dualism with the virtue of moderation and a non-dualist process philosophy. By connecting the mental and environmental ecologies in management, this article suggests that productivist philosophy of management supports overshoot and burnout, and hence should be rejected. 


\section{Conclusion}

The article proposes that the productivist philosophy of management, which assumes measurable productivity and growth as the purpose of management, poorly matches with the aims of circular economy and sustainability, as it lacks an idea of limits. The productivist principle, of having ever more output, is claimed to underlie both burnout and overshoot in the organisational context, as the productivist philosophy of management overlooks the finite resources in the human psyche and ignores the boundaries in the environment. The human psyche and the environment both require time for recovery, which signifies that those resources are not used. In terms of psyche and the environment, recovery begins when production slows down or comes to a halt. That is, while the most effective way to give the psyches a rest is to not require more output from them, the environment's healing starts when humans intervene less in the processes of nature. The article concludes that the productivist philosophy of management, which denies the limits of human and natural resources, is inherently unsustainable and should be complemented with a more holistic and processual view of organisations, as well as have an aim of peaceful coexistence between all earthbound objects. This signifies acknowledging the caring for human and non-human needs both now and in future by applying the idea of moderation to production of goods and services.

Acknowledgements The study was presented at the Corporate Responsibility Research Conference 2017 in Seville, Spain. The authors would like to thank the organisers and participants of the conference. This project has received funding from the European Union's Horizon 2020 research and innovation programme under the Marie Sklodowska-Curie grant agreement No 707652.

Open Access This article is distributed under the terms of the Creative Commons Attribution 4.0 International License (http:/creativecommons.org/licenses/by/4.0/), which permits unrestricted use, distribution, and reproduction in any medium, provided you give appropriate credit to the original author(s) and the source, provide a link to the Creative Commons license, and indicate if changes were made.

Publisher's Note Springer Nature remains neutral with regard to jurisdictional claims in published maps and institutional affiliations.

\section{References}

Althusser, L. [1995] 2014. On the reproduction of capitalism: Ideology and ideological state apparatuses. Orig: Sur la reproduction. Translated by Goshgarian G. M. London: Verso.

Andersson, L.M., S.E. Jackson, and S.V. Russell. 2013. Greening organizational behavior: An introduction to the special issue. Journal of Organizational Behavior 34: 151-155.

Barnosky, A.D., E.A. Hadly, J. Bascompte, E.L. Berlow, J.H. Brown, M. Fortelius, et al. 2012. Approaching a state shift in Earth/'s biosphere. Nature 486 (7401): 52-58.

Bateson, G. 1972. Steps to an ecology of mind: Collected essays in anthropology, psychiatry, evolution, and epistemology. Chicago: University of Chicago Press.

Bateson, G. 1979. Mind and nature: A necessary Unity. New York: E. P. Dutton.

Bezes, P., Demazière, D., Le Bianic, T., Paradeise, C., Normand, R., Benamouzig, D., Pierru, F., \& Evetts, J. (2012). New public management and professionals in the public sector. What new patterns beyond opposition? Sociologie du travail 54: e1-e52.

Bissing-Olson, M., A. Iyer, K. Fielding, and H. Zacher. 2013. Relationships between Daily affect and proenvironmental behavior at work: The moderating role of pro-environmental attitude. Journal of Organizational Behavior 34 (1): 156-175.

Böhm, S., Z.P. Bharucha, and J. Pretty. 2015. Ecocultures: Blueprints for Sustainable Communities. Oxon and New York: Routledge. 
Bonnedahl, K. J., \& Caramujo, M. J. 2018. Beyond an absolving role for sustainable development: Assessing consumption as a basis for sustainable societies. Sustainable Development. Ahead of print: https:/doi. org/10.1002/sd.1862.

Bonnedahl, K.J., and P. Heikkurinen. 2019. Strongly sustainable societies: Organising human activities on a hot and full earth. London: Routledge.

Boxall, P., and K. Macky. 2014. High-involvement work processes, work intensification and employee wellbeing. Work, Employment and Society 28 (6): 963-984.

Brinkmann, Svend 2016. Diagnostic Cultures. A cultural approach to the Pathologization of modern life. London: Routledge.

Brown, P., and A. Hesketh. 2004. The mismanagement of talent: Employability and jobs in the knowledge economy. Oxford: Oxford University Press.

Bültmann, U., K.B. Christensen, H. Burr, T. Lund, and R. Rugulies. 2008. Severe depressive symptoms as predictor of disability pension: A 10-year follow-up study in Denmark. European Journal of Public Health 18 (3): 232-234.

Burke, R.J., and C.L. Cooper. 2000. The new organizational reality: transition and renewal. In The Organization in Crisis: Downsizing, restructuring, and privatization, ed. R.J. Burke and C.L. Cooper. Oxford: Blackwell.

Casey, C. 1995. Work, self and society: After industrialism. London: Routledge.

Chertow, M.R. 2000. The IPAT equation and its variants. Journal of Industrial Ecology 4 (4): 13-29.

Clayton, S., P. Devine-Wright, J. Swim, M. Bonnes, L. Steg, L. Whitmarsh, and A. Carrico. 2016. Expanding the role for psychology in addressing environmental challenges. American Psychologist 71 (3): 199.

Daily, G.C., and P.R. Ehrlich. 1992. Population, sustainability, and Earth's carrying capacity. BioScience 42 (10): $761-771$.

Dale, K. 2005. Building a social materiality: Spatial and embodied politics in organizational control. Organization 12 (5): 649-678.

Dewe, Philip J., Michael P. O’Driscoll, and Cary L. Cooper. 2012. Coping with work stress: A review and critique. Chichester: Wiley-Blackwell.

Dibben, M. \& D'Arcy 2015. Process and Business Management: A Short Note on how Process Thinking might help bring about a more Hospitable World. Available at http:/www.jesusjazzbuddhism.org/. Accessed 1 Nov 2018.

Eagleton, T. 2011. Why Marx was right? New Haven: Yale University Press.

Ecological Economics 2017. Journal webpage. Available at: https://www.journals.elsevier.com/ecologicaleconomics/. Accessed 15 July.

Finley, E. 2018. Beyond the limits of nature: A social-ecological perspective on degrowth as a political ideology. Capitalism Nature Socialism: 1-7.

Fisher, A. 2013. Radical ecopsychology: Psychology in the service of life. New York: Suny Press.

Foster, J.B. 2009. Ecological revolution - Making peace with the planet. New York: Monthly Review Press.

Foster, J.B., and P. Burkett. 2000. The dialectic of organic/inorganic relations: Marx and the Hegelian philosophy of nature. Organization \& Environment 13 (4): 403-425.

Foster, J.B., R. York, and B. Clark. 2010. The ecological rift: Capitalism's war on earth. New York: Monthly Review Press.

Georgescu-Roegen, N. 1999. The entropy law and the economic process. In iUniverse. NE: Lincoln.

Glavas, A. 2016. Corporate social responsibility and organizational psychology: An integrative review. Frontiers in Psychology 7: 144.

Green, F. 2004. Work intensification, discretion, and the decline in well-being at work. Eastern Economic Journal 30: 615-625.

Green, F. 2006. Demanding work: The paradox of job quality in the affluent economy. New Jersey: Princeton University Press.

Grugulis, I., S. Vincent, and G. Hebson. 2003. The rise of the 'network organisation' and the decline of discretion. Human Resource Management Journal 13 (2): 45-59.

Guattari, F. [1989] 2000. The three ecologies. London: The Athlne Press.

Gupta, S. 2017. The 'Indian philosophy of consciousness' and its relevance to 21 st century business management. Philosophy of Management 16 (1): 35-54.

Hart, S.L. 1995. A natural-resource-based view of the firm. Academy of Management Review 20 (4): 986-1014.

Harvey, D. 2014. Seventeen contradictions and the end of capitalism. New York: Oxford University Press.

Heikkurinen, P. 2017. Sustainability and peaceful coexistence for the Anthropocene. London: Routledge.

Heikkurinen, P. 2018. Degrowth by means of technology? A treatise for an ethos of releasement. Journal of Cleaner Production 197: 1654-1665.

Heikkurinen, P. 2019. Degrowth: A metamorphosis in being. Environment and Planning E: Nature and Space (in press).

Heikkurinen, P., and J. Mäkinen. (2018). Synthesising corporate responsibility on organisational and societal levels of analysis: An integrative perspective. Journal of Business Ethics 149 (3): 589-607.

Heikkurinen, P., J. Rinkinen, T. Järvensivu, K. Wilén, and T. Ruuska. 2016. Organising in the Anthropocene: An ontological outline for ecocentric theorising. Journal of Cleaner Production 113: 705-714. 
Hensing, G., L. Anderson, and S. Brage. 2006. Increase in sickness absence with psychiatric diagnosis in Norway: A general population-based epidemiologic study of age, gender and regional distribution. $B M C$ Medicine 4: 19.

Hornborg, A. 2014. Ecological economics, Marxism, and technological progress: Some explorations of the conceptual foundations of theories of ecologically unequal exchange. Ecological Economics 105: 11-18.

Horwitz, A.V. 2002. Creating mental illness. Chicago: University of Chicago Press.

IPCC (Intergovernmental Panel on Climate Change) 2014. 5th Assessment Report. Climate change 2014: Impacts, Adaption, and Vulnerability.

Jackson, T. 2009. Prosperity without growth: Economics for a finite planet. London: Earthscan.

Järvisalo, J., Andersson, B., Boedeker, W. \& Houtman, I. (eds.) 2005. Mental disorders as a major challenge in prevention of work disability. Social security and health reports 66 . Helsinki: Kela.

Jones, D.S. 2013. Masters of the universe. Hayek, Friedman and the birth of neoliberal politics. Princeton: Princeton University Press.

Kivimäki, M., J. Vahtera, A. Griffiths, T. Cox, and L. Thomson. 2000. Sickness absence and organizational downsizing. In The Organization in Crisis: Downsizing, restructuring, and privatization, ed. R.J. Burke and C.L. Cooper. Oxford: Blackwell.

Klein, N. 2014. This changes everything: Capitalism vs. the climate. New York: Simon \& Schuster.

Knights, D. 1997. Organization theory in the age of deconstruction: Dualism, gender and postmodernism revisited. Organization Studies 18 (1): 1-19.

Knudsen, A.K., S. Øverland, H.F. Aakvaag, S.B. Harvey, M. Hotopf, and A. Mykletun. 2010. Common mental disorders and disability pension awarded: Seven year follow-up of the HUSK study. Journal of Psychosomatic Research 69 (1): 59-67.

Kuokkanen, A., P. Varje, and A. Väänänen. 2013. Transformation of the Finnish employee ideal in job advertisements from 1944 to 2009. Acta Sociologica 56 (3): 213-226.

Latouche, Serge 2007. Petit traité de la décroissance sereine. Mille et Une Nuits.

Marx, K. [1894] 1959. Capital: A Critique of Political Economy, Volume 3: The Pro- cess of Capitalist Production as a Whole. Orig: Das Kapital: Kritik der politischen Ökonomie, Buch 3: Der Gesamtprozess der kapitalistischen Produktion (1894). Translated by Fernbach, D. London: Penguin Classics in association with New Left Review.

Marx, K. [1867] 1973. Capital: A Critique of Political Economy, Volume 1: The Pro- cess of Capitalist Production. Orig: Das Kapital: Kritik der politischen Ökonomie, Buch 1: Der Produktionsprocess des Kapitals. Translated by Moore, S. and Aveling, E. New York: International Publishers.

Marx, K. [1844] 2011. Economic \& Philosophic Manuscripts of 1844. Orig: Ökonomisch-philosophische Manuskripte aus dem Jahre. Translated by Milligran M. Masnfield Centre: Martino Publishing.

Meadows, D., D. Meadows, J. Randers, and W. Behrens. 1972. The limits to growth. New York: New American Library, NY.

Meadows, D., D. Meadows, and J. Randers. 2002. The limits to growth: The 30-year update. White River Junction: Chelsea Green Publishing.

Miller, P., and N. Rose. 2008. Governing the present. Administering economic, social and personal life. Cambridge: Polity Press.

Moore, J.W. 2015. Capitalism in the web of life. Ecology and the accumulation of capital. New York: Verso.

Newton, T. 1995. Managing' stress: Emotion and power at work. London: Sage.

Nicholson, N., and R. White. 2006. Darwinism-A new paradigm for organizational behavior? Journal of Organizational Behavior 27 (2): 111-119.

Polanyi, K. ([1944] 1968). The great transformation. Beacon Press: MA, Boston.

Purser, R. E., Park, C., \& Montuori, A. (1995). Limits to anthropocentrism: Toward an ecocentric organization paradigm?. Academy of Management Review 20 (4): 1053-1089.

Reed, E.S. 1992. Knowers talking about the known: Ecological realism as a philosophy of science. Synthese 92 (1): 9-23.

Robertson, J., and J. Barling. 2013. Greening organizations through leaders' influence on employees' proenvironmental behaviors. Journal of Organizational Behavior 34 (2): 176-194.

Robinson, W.I. 2014. Global capitalism and the crisis of humanity. New York: Cambridge University Press.

Rockström, J., W. Steffen, K. Noone, Å. Persson, S.F.I.I.I. Chapin, et al. 2009. A safe operating space for humanity. Nature 461: 472-475.

Ruuska, T. 2017. Reproduction of capitalism in the 21st century: Higher education and ecological crisis. Aalto University publication series, doctoral dissertations 97/2017. Helsinki: Unigrafia.

Sandberg, J., and H. Tsoukas. 2015. Making sense of the sensemaking perspective: Its constituents, limitations, and opportunities for further development. Journal of Organizational Behavior 36 (S1).

Scharff, C. 2015. The psychic life of neoliberalism: Mapping the contours of entrepreneurial subjectivity. Theory, Culture \& Society 33 (6): 107-122.

Schumacher, E. F. [1973] 1974. Small is beautiful: A study of economics as if people mattered. London: Abacus. 
Sennett, R. 1998. The corrosion of character: The personal consequences of work in the new capitalism. New York: W.W. Norton.

Severino E [1982] 2016 The essence of nihilism. Translated by Donis G. London and New York: Verso.

Sheard, S. 2009. Continental philosophy and Organisational studies: A critique of aspects of postmodern thought in OS. Philosophy of Management 7 (3): 43-59.

Shorter, Edward. 1998. A history of psychiatry: From the era of the asylum to the age of Prozac. London: Wiley. Shrivastava, P. 1994. Castrated environment: Greening organizational studies. Organization Studies 15 (5): $705-726$. Shrivastava, P. 2015. Organizational sustainability under degrowth. Management Research Review 38 (6): 1-1.

Starik, M., and G.P. Rands. 1995. Weaving an integrated web: Multilevel and multisystem perspectives of ecologically sustainable organizations. Academy of Management Review 20 (4): 908-935.

Steffen, W., K. Richardson, J. Rockström, S.E. Cornell, I. Fetzer, E.M. Bennett, et al. 2015. Planetary boundaries: Guiding human development on a changing planet. Science 347: 1259855.

Taylor, C. 2007. A Secular Age. Cambridge and London: The Belknap Press of Harvard University Press.

Väänänen, A., E. Anttila, J. Turtiainen, and P. Varje. 2012. Formulation of work stress 1960-2000: Analysis of scientific works from the perspective of historical sociology. Social Science \& Medicine 75 (5): 784-794.

Väänänen, A., M. Murray, and A. Kuokkanen. 2014. The growth and stagnation of work stress. Publication trends and scientific presentations 1960-2011. History of Human Sciences 27 (4): 116-138.

Vetlesen, A.J. 2016. The denial of nature: Environmental philosophy in the era of global capitalism. London: Routledge.

Victor, P.A. 2008. Managing without growth: Slower by design, not disaster. Chelteham: Edward Elgar.

Wainwright, D., and M. Calnan. 2002. Work stress: The making of a modern epidemic. Buckingham: Open University Press.

Wallerstein, I. [1983] 2003. Historical capitalism and capitalist civilization. London: Verso.

Ward, J.D., P.C. Sutton, A.D. Werner, R. Costanza, S.H. Mohr, and C.T. Simmons. 2016. Is decoupling GDP growth from environmental impact possible? PLoS One 11 (10): e0164733.

Whitehead, A. N. [1919] 1964. The concept of nature. Cambridge University Press: Cambridge.

Wiedmann, T., H. Schandl, M. Lenzen, D. Moran, S. Suh, J. West, and K. Kanemoto. 2015. The material footprint of nations. PNAS 112 (20): 6271-6276.

Wood, E.M. 2002. The origin of capitalism. A longer view. London: Verso.

Wright, C., and D. Nyberg. (2012). Working with passion: Emotionology, corporate environmentalism and climate change. Human Relations 65 (12): 1561-1587.

York, R. 2006. Ecological paradoxes: W.S. Jevons and paperless office. Human Ecological Review 13 (2): $143-147$.

Pasi Heikkurinen is Lecturer in Business and Sustainable Change at the University of Leeds, Sustainability Research Institute; Lecturer in Management at the University of Helsinki, Department of Economics and Management; and Docent in Sustainability and Organizations at the Aalto University School of Business. His research project is a phenomenology of sustainability. The focus of his work is on questions concerning ethics and technology in relation to sustainable change, and in particular in the context of food and agriculture.

Dr. Toni Ruuska is a postdoctoral researcher at the University of Helsinki, Department of Economics and Management. In his postdoctoral research he is studying the politics of self-sufficiency. His research interest locate broadly in the fields of political economy and ecology, as well in understanding the theoretical, practical and ethical underpinnings of sustainable organisation of societies.

Anna Kuokkanen (DrSocSci) is a Postdoctoral Researcher at the University of Helsinki in the discipline of Political History. She has a background in sociology, social history and critical management studies. She is specialized in societal and work life changes and using qualitative data and methods. Her research interests include the dissemination of management ideas, the historical construction of employee ideals and the rise of mental vulnerability in working life. Currently, she is working on a project that examines the development of employee participation discourse in Finnish personnel management..

Sally Russell is an Associate Professor in the Sustainability Research Institute at the University of Leeds, UK. She leads the research group 'Businesses and Organisations for Sustainable Societies'. Her research focuses broadly on behaviour change for sustainability with a particular emphasis on how emotional reactions to environmental issues affect subsequent behaviour and decision making - both within and outside organisations. 